\title{
Enhanced expression of G-protein coupled estrogen receptor (GPER/GPR30) in lung cancer
}

\author{
Venkatakrishna Rao Jala ${ }^{{ }^{*}}$, Brandie N Radde ${ }^{2}$, Bodduluri Haribabu ${ }^{1}$ and Carolyn M Klinge ${ }^{2}$
}

\begin{abstract}
Background: G-protein-coupled estrogen receptor (GPER/GPR30) was reported to bind 17ß-estradiol ( $\left.E_{2}\right)$, tamoxifen, and ICI 182,780 (fulvestrant) and promotes activation of epidermal growth factor receptor (EGFR)-mediated signaling in breast, endometrial and thyroid cancer cells. Although lung adenocarcinomas express estrogen receptors $a$ and $\beta$ (ERa and ERß), the expression of GPER in lung cancer has not been investigated. The purpose of this study was to examine the expression of GPER in lung cancer.

Methods: The expression patterns of GPER in various lung cancer lines and lung tumors were investigated using standard quantitative real time PCR (at mRNA levels), Western blot and immunohistochemistry (IHC) methods (at protein levels). The expression of GPER was scored and the pairwise comparisons (cancer vs adjacent tissues as well as cancer vs normal lung tissues) were performed.
\end{abstract}

Results: Analysis by real-time PCR and Western blotting revealed a significantly higher expression of GPER at both mRNA and protein levels in human non small cell lung cancer cell (NSCLC) lines relative to immortalized normal lung bronchial epithelial cells (HBECs). The virally immortalized human small airway epithelial cell line HPL1D showed higher expression than HBECs and similar expression to NSCLC cells. Immunohistochemical analysis of tissue sections of murine lung adenomas as well as human lung adenocarcinomas, squamous cell carcinomas and non-small cell lung carcinomas showed consistently higher expression of GPER in the tumor relative to the surrounding non-tumor tissue.

Conclusion: The results from this study demonstrate increased GPER expression in lung cancer cells and tumors compared to normal lung. Further evaluation of the function and regulation of GPER will be necessary to determine if GPER is a marker of lung cancer progression.

Keywords: GPER, GPR30, Estrogen, Estrogen receptor, Lung cancer, Protein expression, Immunohistochemistry, Tissue microarray

\section{Background}

Lung cancer is the leading cause of cancer deaths in United State of America both in men and women [1]. Although controversial, some epidemiologic data indicate that women have a higher risk of lung adenocarcinoma, a type of non-small cell lung cancer (NSCLC), compared to men, independent of smoking status [2,3]. One recent study reported reduced risk of lung cancer mortality in breast cancer patients, who were taking antiestrogens [4]. This study also found that women

\footnotetext{
* Correspondence: jvrao001@louisville.edu

'James Graham Brown Cancer Center, Department of Microbiology and Immunology, 505 South Hancock Street, Room 323, CTR Building, Louisville, KY 40202, USA

Full list of author information is available at the end of the article
}

taking antiestrogens had a significant lower risk of developing lung cancer [4]. While it is known that estrogens induce maturation of normal lung tissue [5,6], their role in lung cancer initiation and progression remains unclear.

Estrogens regulate a wide variety of biological processes including differentiation, cell proliferation, apoptosis, inflammation and metabolism primarily by binding to two receptors: ER $\alpha$ and ER $\beta$ (ERs will refer to both subtypes) [7-12]. ER $\alpha$ and ER $\beta$ belong to the nuclear receptor superfamily of ligand-activated DNA binding transcription factors (reviewed in [13]). The classical mechanism of $E_{2}$ action involves binding to ERs to form homo- or hetero- dimers followed by direct binding to estrogen response elements (ERE) or tethering to other

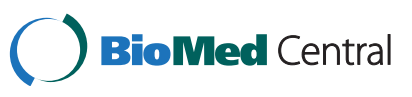


DNA bound-transcription factors, e.g., AP-1, located in the regulatory regions of target genes [14]. The resulting recruitment of co-activators and chromatin remodeling complexes alters gene transcription leading to physiological responses within hours following $E_{2}$ exposure. Estrogens also promote various types of cancers including breast cancer and ablation of estrogen synthesis or ER activities are effective treatments to prevent disease recurrence [15].

$E R \alpha$ and ER $\beta$ proteins are expressed in primary lung tumors (reviewed in [5]). In contrast to breast cancer, ER $\beta$ levels are $\sim$ twice that of ER $\alpha$ levels in lung cancers $[16,17]$. It was also reported that NSCLC cells express ER $\alpha$ and ER $\beta$ and respond transcriptionally to $\mathrm{E}_{2}$ [18-22]. In addition to the classical genomic mechanism of estrogen action, numerous studies have demonstrated that $\mathrm{E}_{2}$ rapidly (in $<5 \mathrm{~min}$.) activates plasma membrane initiated signaling cascades through G-Protein dependent pathways, including release of intracellular calcium, IP3 accumulation, cAMP production, and MAPK activation [23-26]. Both ER $\alpha[27,28]$ and ER $\beta$ [29] appear to localize with protein kinases and other proteins in 'signalosome' complexes in caveolae in the plasma membrane in a cell type-dependent manner. In this context, the non-genomic $\mathrm{E}_{2}$-ER $\beta$ dependent signaling and cooperation between $\beta 1$ adrenergic receptor and ER $\beta$ signaling pathways may contribute to the smoking-associated lung carcinoma progression in women [30]. There is also considerable evidence for a role for $E_{2}$ activation of membrane-associated ER crosstalk with epidermal growth factor receptor (EGFR) (reviewed in [10,31-38]).

GPR30/GPER (also known as DRY12, FEG-1, LERGU, LyGPR, CMKRL2, LERGU2 and GPCR-Br) was first identified as a GPCR involved in membrane-mediated $E_{2}$ - signaling [39-42]. The precise role of GPER, its intracellular location, and role in mediating estrogen function remains controversial $[27,43-46]$. GPER was reported to bind $E_{2}$ with high affinity $(\mathrm{Kd}=3-7 \mathrm{nM})$ and to activate multiple intracellular signal transduction pathways, e.g., calcium mobilization, cAMP production, PI3K activation and ERK1/2 activation in a G-protein dependent manner. Northern blot, real time PCR, and immunohistochemistry (IHC) analyses showed that GPER is expressed in placenta, heart, lung, liver, prostate, bone marrow and fetal liver [47], but a complete atlas of GPER protein expression and its functional roles are yet to be established. Here, we report for first time, the expression patterns of GPER in lung cancer cell lines and human lung cancer tissues. The results from our studies indicate that the expression of GPER is elevated in lung tumors compared to normal/adjacent lung tissues.

\section{Results}

\section{Expression of GPER in lung cancer cell lines}

Although at the time of its cloning, GPER was shown to be expressed in normal human lung by Northern blot [48], its expression in lung cancer cell lines or lung tumors has not been examined. The mRNA levels of GPER were determined in human NSCLC, lung adenocarcinoma cell lines: A549, NCI-H23, NCI-H1299, NCI-H1792, NCI-H1395, NCI-H1435, NCI-H1793, NCI-H1944, NCI-H2073 (all purchased from ATCC); immortalized, but not transformed, human bronchial epithelial lung cell lines obtained from Dr. John D. Minna, UT Southwestern: HBEC3-KT, HBEC2-E and HBEC2-KT [49]; the SV40-immortalized human small airway epithelial cell line HPL1D, derived from a female non-smoker without lung cancer [50], was kindly provided to us by Dr. T. Takahashi (Center of Neurological Diseases and Cancer, Nagoya University Graduate School of Medicine, Nagoya, Japan) and Dr. Hildegard M. Schuller, Department of Pathobiology, College of Veterinary Medicine, University of Tennessee, Knoxville, TN) [51,52]; and the human MCF-7 breast cancer cell line was obtained from ATCC as a positive control for GPER [44]. Both semi-quantitative PCR (Additional file 1: Figure S1) and real time quantitative PCR (Figure 1A) were performed. These results provide the first evidence of GPER expression in human lung adenocarcinoma cell lines.

\section{Increased expression of GPER in lung cancer lines}

To more accurately examine the mRNA levels of GPER, quantitative real time PCR was performed on lung cancer and normal HBEC lines. As shown in Figure 1A and Table 1, the expression level of GPER is higher in most of the lung cancer cell lines compared to HBECs and HPL1D cells. In 12 lung cancer cell lines tested, GPER relative overexpression ranged from 2 to 10 fold compared to normal HBECs (Table 1). The protein levels of GPER in representative lung adenocarcinoma cell lines, HBEC2-KT, HBEC3-KT, HPL1D, and in MCF-7 breast cancer cells were determined by Western blots using three different antibodies obtained from different commercial sources (Figure 1B-D). Each of the antibodies recognized a number of bands that have, in the case of Novus NBP1-31239 and NLS 4271, been demonstrated by using blocking peptides to be specific and are considered to be various glycosylated forms of GPER [53], or to indicate homodimerization or interaction with other proteins in detergent-resistant complexes [54-56]. Surprisingly, the expression of GPER mRNA and protein are not concordant, nor was there concordance between GPER levels with the three antibodies tested in each cell line, although consistency was observed in H1793 cells for MCF-7 and T47D cells with the 2 Novus antibodies, between the NLS4272 and SC-48524 for H23 cells. Nonetheless, these data for the first time demonstrate GPER expression in lung adenocarcinoma cells and normal lung cells and suggest that the levels of GPER expression are, on average, higher in the NSCLC cells 


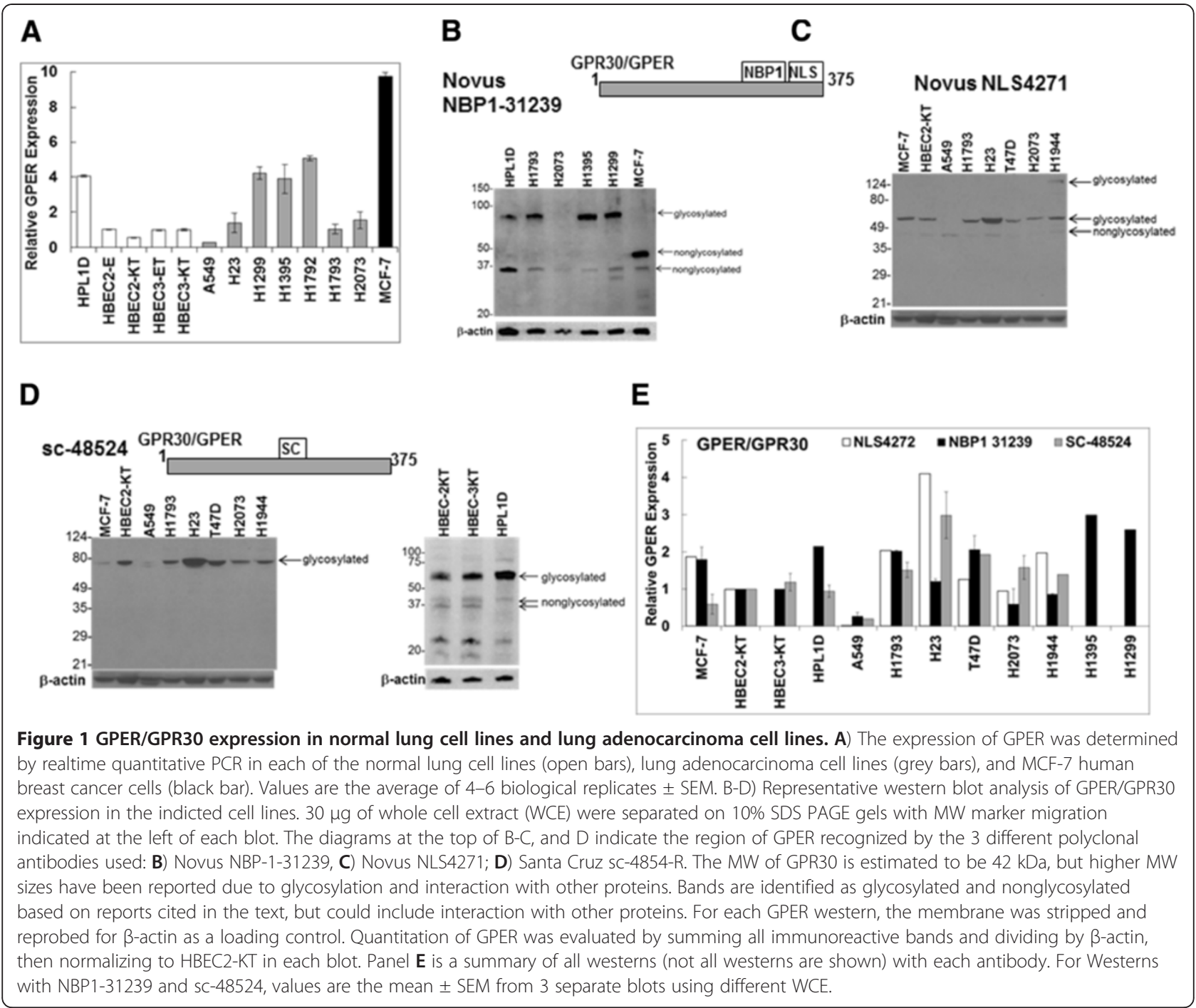

Table 1 GPER mRNA fold level change in lung cancer cell lines compared to normal lung epithelial cells

\begin{tabular}{llllll}
\hline Cell line & Sex of patient & Smoker/non-smoker & Level of GPR30 & & \\
\cline { 4 - 5 } & & & HBEC 3ET as baseline & HBEC 2E as baseline & HBEC 2KT as baseline \\
\hline HBEC 3ET & & 1.00 & 0.96 & 1.74 \\
HBEC 2E & & 1.04 & 1.00 & 1.81 \\
HBEC 2KT & & 0.57 & 0.55 & 1.00 \\
HPL1D & Female & Nonsmoker no lung cancer & 4.06 & 1.19 & 0.74 \\
A549 & Male & Unknown & 0.29 & 0.28 & 0.5 \\
NCl-H1792 & Male & Smoker & 5.15 & 4.96 & 8.99 \\
NCl-H23 & Male & Smoker & 1.97 & 1.89 & 3.43 \\
NCI-H1299 & Male & Smoker & 4.67 & 4.50 & 8.15 \\
NCI-H2073 & Female & Smoker & 1.09 & 1.05 & 1.90 \\
NCI-H1395 & Female & Smoker & 4.80 & 4.63 & 8.38 \\
NCI-H1944 & Female & Smoker & 2.56 & 2.46 & 4.46 \\
NCl-H1793 & Female & Non-Smoker & 1.34 & 1.29 & 2.34 \\
MCF7 & Female & Unknown & 9.74 & 9.38 & 16.98
\end{tabular}


compared to the average of the 3 normal lung cell lines. It is possible that the discordant findings between transcript and protein levels result from altered splicing or mutations in the C-terminus of GPER, but this idea requires further investigation. Three SNPs were described in GPER with one resulting in a single Pro16Leu aa change within the coding region [57]. Additionally, it is also possible that specificity/affinity as well as quality of these GPER antibodies may vary between different sources and the impact of glycosylation and other post-transcriptional modifications on antibody interaction is also an issue.

\section{Elevated levels of GPER expression in mouse and human lung cancer tissues}

The expression pattern of GPER in normal and lung cancer tissues was examined using Immunohistochemistry (IHC) staining.

a) Mouse lung tumors: The IHC was performed to determine the expression of GPER and proliferating cell nuclear antigen (PCNA) in paraffin embedded tissue sections of mouse lung tumors. The mouse lung tumors were induced using 3-methylcholanthrene -butylated hydroxytoluene (MCA-BHT). The representative $\mathrm{H} \& \mathrm{E}$ stained (Figure $2 \mathrm{~A}$ ) and IHC images of mouse lung tumor sections are shown (Figure 2B-D). The isotype control antibody showed no positive staining (Figure $2 \mathrm{C}$ ). The expression of
GPER and PCNA staining appear to localize to the same regions (Figure 2D) suggesting that GPER is overexpressed in proliferating tumor cells.

b) Human lung tumors: The human multiple lung cancer tissue arrays with unmatched normal adjacent tissues (US Biomax Inc \#LC242 (10 cases) and LC1005 (77 cases) were used to determine the expression of GPER patterns. A human breast cancer test tissue array was used with self-matching or unmatched normal adjacent tissues (US Biomax Inc \#BR241) as a positive control. The representative lung tumor shown in Figure 3A is from male (age 57) and classified as adenocarcinoma, Grade II and malignant tumor. This tissue micro array LC242 represents 10 cases of lung tumor with 2 nonneoplastic tissue (duplicated core in $1.5 \mathrm{~mm}$ size per case) sections. The expression of GPER in another TMA (LC1005), containing 77 cases of lung cancer tissues along with normal (8 cases) and cancer adjacent tissues (42 cases) were also analyzed. The representative images of $\mathrm{H}$ and $\mathrm{E}$ and $\mathrm{IHC}$ analysis of GPER expression in different types of lung cancers are shown in Figure 3A-D along with normal adjacent lung tissues. The positive staining for GPER in human breast cancer (Infiltrating ductal carcinoma not otherwise specified (NOS), Grade II, malignant) is much stronger compared to non-tumor regions of matched adjacent tissues, which served as positive control in these IHC studies (Figure 3E-F).
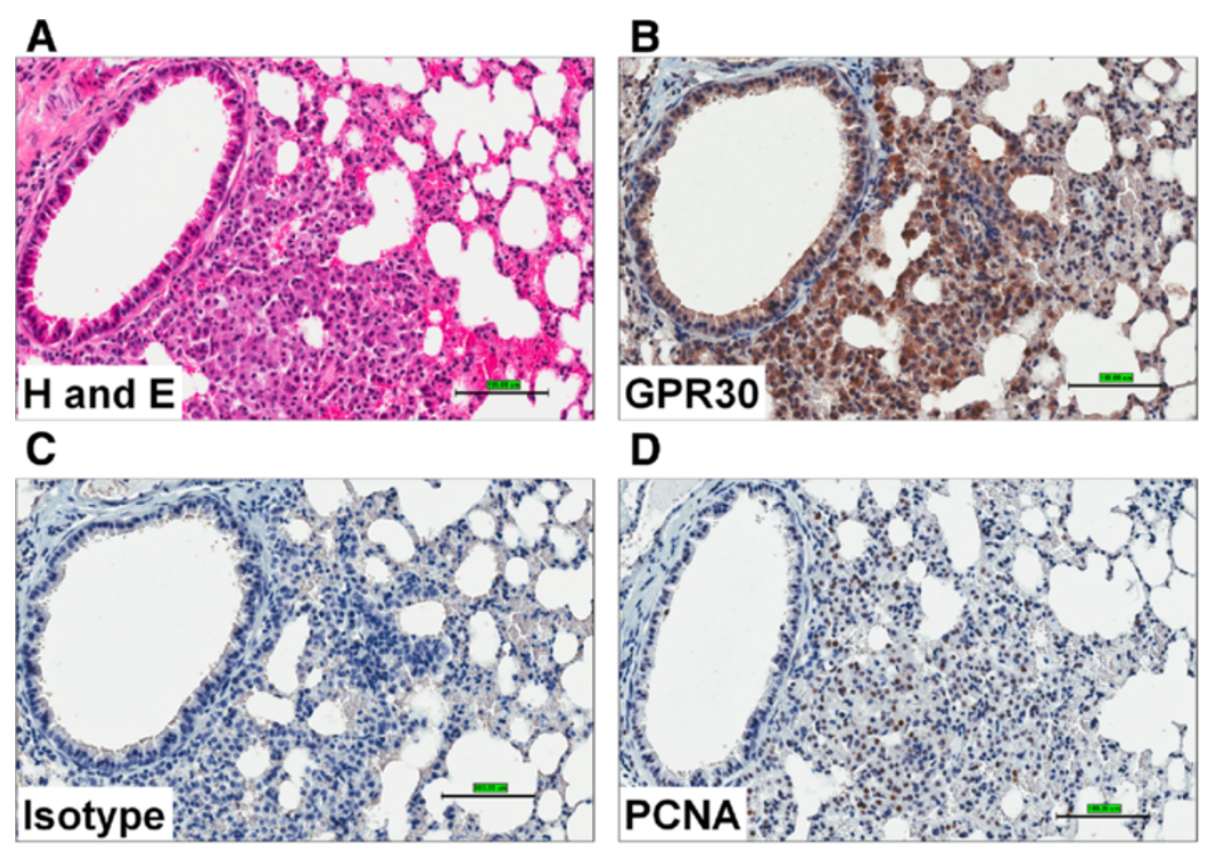

D

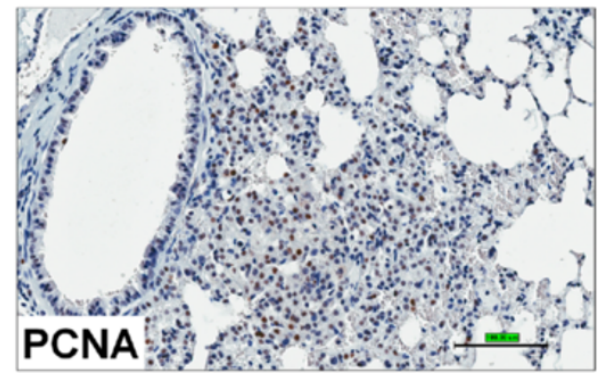

Figure 2 Expression of GPER/GPR30 in mouse lung tumors. (A) IHC analyses of mouse lung cancer (induced with MCA-BHT). The whole lungs were stained with H \& E (A), GPR30 C-terminal antibody (Novus Biologicals, $10 \mu \mathrm{g} / \mathrm{ml}$ ) (B) along with isotype control (C) and PCNA (D) using standard IHC protocols. 

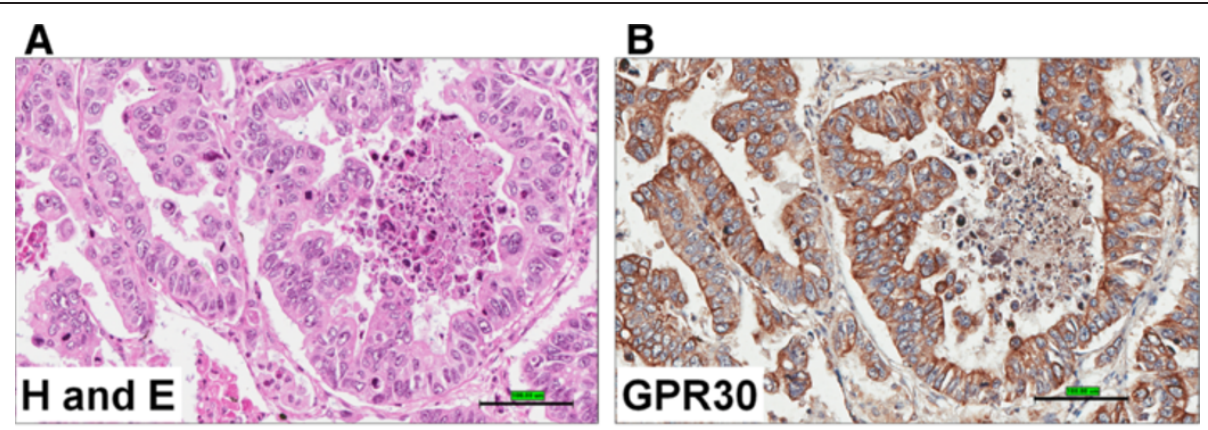

C

D
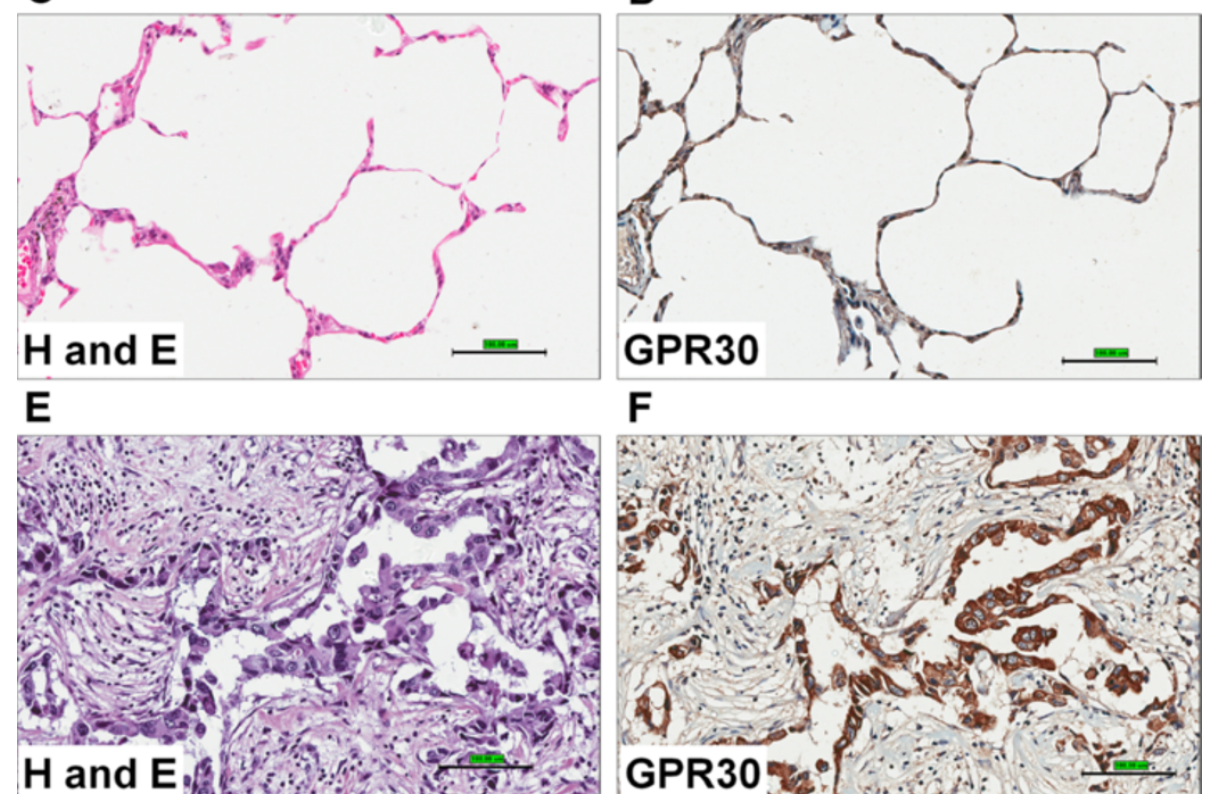

$\mathbf{F}$

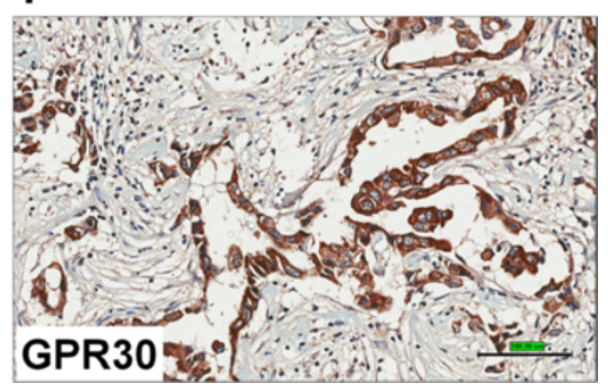

Figure 3 GPER/GPR30 expression in human lung and breast tumors. The TMA slides, 'Multiple lung cancer test array with unmatched normal adjacent tissue' (US BioMax Inc, \#LC242) and 'human breast cancer test tissue array with self-matching or unmatched normal adjacent tissues' (US Biomax Inc \#BR241) were stained with H\&E and anti-GPR30 (10 $\mathrm{mg} / \mathrm{ml})$. (A-B). The representative tissue spot/core images of Hand E (A) and GPR30 (B) staining for lung cancer (adenocarcinoma) are shown. (C-D). The representative normal lung tissue for $\mathrm{H}$ and $\mathrm{E}(\mathbf{C})$ and GPR30 staining (D) are shown. (E-F) The breast cancer TMA slides were stained with H\&E and anti-GPR30 as a positive control for GPR30 expression. The images were collected at 200X magnification using Aperio image scope. The scale bars indicate $100 \mu \mathrm{m}$.

The expression of GPER is also elevated in squamous cell carcinoma and large cell carcinoma (Figures 4 and 5). The overall results suggest that the GPER is overexpressed in lung cancer tissues compared to normal/adjacent lung tissues.

c) Scoring of GPER staining: The scoring of the GPER staining was performed by two independent pathologists. The scoring pattern for GPER staining as follows. Score 0, negative staining for all cells; score $1+$, weakly positive for cytosolic staining in $<10 \%$ of cells; score $2+$, moderate to strong positive staining covering between 10 to $50 \%$ of cells and score $3+$, strongly positive staining including $>50 \%$ cells (Figure 6). All the scoring was done in a blinded manner regarding tumor type/stage data. The comparison between two non-parametric groups was done using Mann-Whitney U test. The GPER scores were compared between the cancer tissues and cancer-adjacent tissue/normal lung tissue. The IHC scores were grouped into two groups, negative or weakly positive $(0$ and $1+)$ and moderately to strongly positive $(2+$ and $3+$ ) (Table 2$)$. IHC quantification (Figure 6 and Table 2) suggests that GPER is significantly overexpressed in lung tumors compared to either normal lung or cancer-adjacent tissues. GPER positive staining (moderate intensity) was observed on the alveolar macrophages in the normal lungs. We did not observe any detectable GPER IHC positive staining in the normal lung epithelium. GPER is significantly overexpressed ( $2-3$ score) in $>80 \%$ the adenocarcinomas $(\mathrm{p}<0.0001), 75 \%$ in large cell carcinoma $(\mathrm{p}<0.0001)$ and $60 \%$ in squamous cell carcinoma $(\mathrm{p}<0.0001)$. Overall, $>76 \%$ of all lung cancer tissues showed 


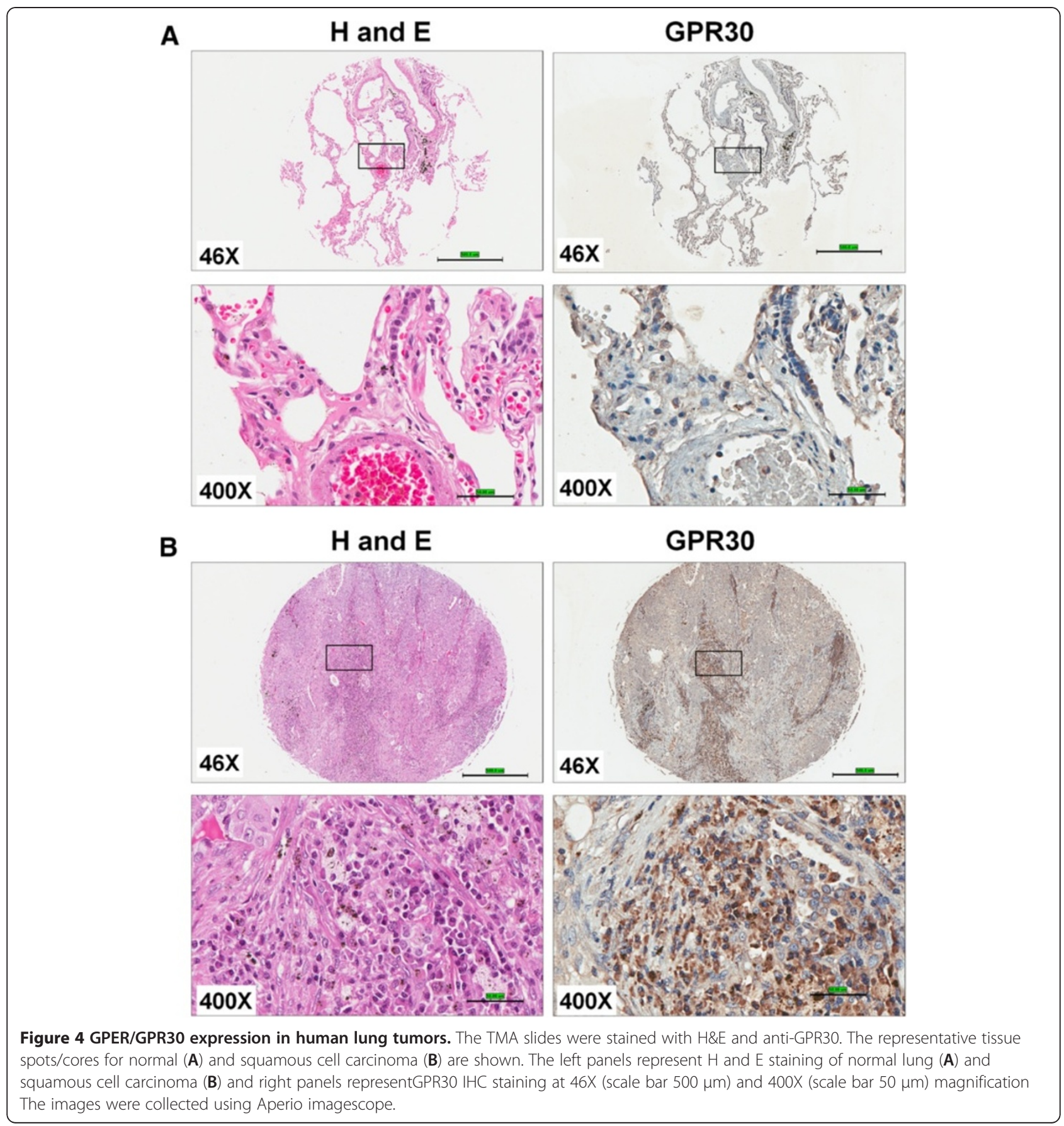

positive GPER staining (score 2 to 3 ) whereas $<3 \%$ of normal lung tissues/adjacent tissues (score 2 to 3 ) showed any detectable GPER expression. We conclude that GPER expression is increased in lung cancer.

\section{Discussion}

GPER is an $E_{2}$ binding, G-protein coupled membrane receptor $[39-42,58]$ that was reported to be overexpressed in breast [40,59] endometrial [60,61], ovarian [62] and thyroid cancers [63]. The results presented here extend these observations to show that different types of lung cancers including adenocarcinomas, squamous cell carcinoma and large cell carcinomas express higher GPER than normal lung tissue.

Here, we demonstrate for the first time that GPER is overexpressed in lung tumors and lung adenocarcinoma cell lines relative to normal lung and immortalized normal lung cell lines, although the expression of GPER transcript in HPL1D cells is higher than HBECs. GPER has been postulated to be involved in $\mathrm{E}_{2}$-activation of 

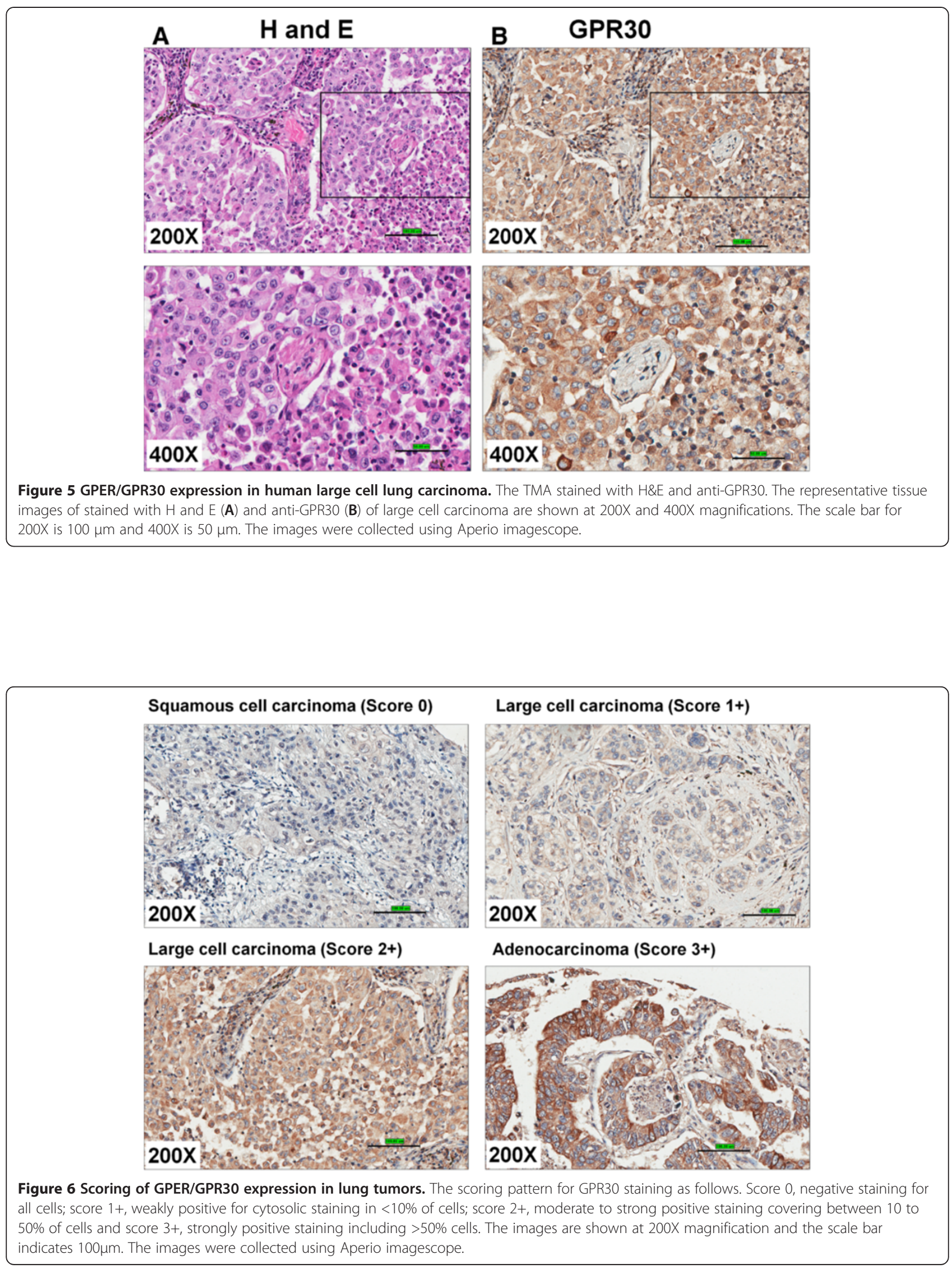
Table 2 GPER IHC scoring in tissue microarrays

\begin{tabular}{|c|c|c|c|c|}
\hline Tissue & Score $0-1+$ & Score $2-3+$ & $\begin{array}{l}P \text {-values (compared with } \\
\text { cancer adjacent tissues) }\end{array}$ & $\begin{array}{l}P \text {-values (compared with } \\
\text { normal lung tissues) }\end{array}$ \\
\hline Adenocarcinoma & 2 of 15 (13.3\%) & 13 of $15(86.7 \%)$ & $P<0.0001$ & $P=0.0007$ \\
\hline Squamous cell carcinoma & 13 of $33(40 \%)$ & 20 of $33(60.0 \%)$ & $P<0.0001$ & $P=0.0024$ \\
\hline Large cell carcinoma & 2 of $8(25 \%)$ & 6 of $8(75 \%)$ & $P<0.0001$ & $P=0.0011$ \\
\hline Metastatic adenocarcinoma & 1 of $6(16.7 \%))$ & 5 of $6(83.3 \%)$ & $P=0.0002$ & $P=0.0013$ \\
\hline Cancer adjacent lung tissue & 41 of $42(97.6 \%)$ & 1 of $42(2.4 \%)$ & & No significant \\
\hline Normal lung tissue & 8 of $8(100 \%)$ & 0 of $8(0)$ & No significant & \\
\hline
\end{tabular}

The scoring pattern for GPR30 staining as follows. Score 0 , negative staining for all cells; score $1+$, weakly positive for cytosolic staining in <10\% of cells; score $2+$, moderate to strong positive staining covering between 10 to $50 \%$ of cells and score $3+$, strongly positive staining including $>50 \%$ cells.

EGFR [38]. Filardo's group showed a link between GPER expression and tumor progression and increased tumor size in breast cancer patients [40]. Recently, GPER overexpression was reported to be independent of ER $\alpha$ expression in breast cancer patient samples, indicating the importance of GPER in ER $\alpha$ negative tumors [64]. GPER and EGFR expression were correlated in endometrial adenocarcinoma [60]. Further, overexpression of GPER in advanced stage endometrial adenocarcinoma correlated with poor survival [60]. Other studies also suggest increased GPER in breast, ovarian and endometrial cancers correlates with disease severity and reduced survival $[40,59,60,62,65]$. These results are in agreement with studies demonstrating association of GPER overexpression in other cancers $[40,59,60,62,64,65]$, although the scoring patterns and correlation of expression levels to disease state may vary among these studies. A limitation of our study is that the average GPER staining scores among different lung cancer grades (I (10 cases), II (30 cases), III (16 cases)) were not significantly different. One other limitation of the current study is that we cannot conclude at this time whether GPER overexpression is cause or consequence of cancer. It is also possible that overexpression of GPER in lung cancers may reflect a defense mechanism to counteract excessive proliferation. Indeed, a recent report by Krakstad et al. showed that loss of GPER in ER $\alpha$-positive endometrial cancers is associated with poor prognosis [66]. Another study showed that the GPER agonist G-1 inhibited $E_{2}$-induced uterine epithelial cell proliferation in mice by repressing MAPK activation, indicating that GPER effects are tissue specific [67]. Because our studies were performed on commercial TMAs, the results cannot be extrapolated to correlate GPER expression levels to disease outcomes. Clearly, this is a next logical step in light of the novel findings.

We observed no differences in GPER expression between adenocarcinoma cell lines or tumors from male and female patients, similar to the previous findings of no difference in ER $\alpha$ or ER $\beta$ expression in NSCLC cells and tumors based on gender [20,68-70]. In Western blots, rather than rely on one GPER antibody in our study, we used 3 different commercial antibodies to determine the correlation between mRNA and protein levels. It is indeed evident from our Western blot data that GPER appears to have different MW forms, likely due to glycosylation [53], dimerization [54,55], and interaction with other membrane proteins [56], and levels in the lung adenocarcinoma cell lines. More trivial explanations for the different staining patterns of GPER in Western blots may be due to differential purity/affinity of the three GPER antibodies as well as their capacity to bind to secondary antibodies. It will be important to determine the nature of these forms by proteomic analysis and gene sequencing to evaluate their biological significance.

The role of GPER as an $\mathrm{E}_{2}$ membrane receptor is controversial and its functional significance is unclear. Some reports suggest that GPER is not an estrogen receptor because it does not bind $E_{2}$ and thus still consider it as an orphan GPCR $[27,71-73]$. The recent identification of estrogen receptor splice variant called ER $\alpha 36$ adds one more layer of complexity to estrogen biology and the role of GPER [72]. ER $\alpha 36$ was reported to be responsible for $\mathrm{E}_{2}$ induced non-genomic signaling rather than GPER [72].

Mechanism-based studies showed that GPER transactivates EGFR in breast cancer cells [38,39,74-76] as well as in thyroid, endometrial and ovarian cancer cell lines $[61,63,77,78]$. Inhibitors of EGFR tyrosine kinase (gefitinib) and ER (fulvestrant, ICI 182,780) were reported to synergize their anti-proliferative effects in NSCLC [19]. Given the importance of EGFR signaling as a therapeutic target in lung cancer $[79,80]$, further examination of the effect of EGF, heregulin, and amphiregulin on GPER expression and function in lung cancer may provide new insights into resistance to EGFR inhibitors and or how estrogens stimulate lung cancer.

\section{Conclusion}

In conclusion, the data presented in this manuscript demonstrate that GPER expression is higher in lung tumors compared to normal lung tissue. While it is not 
yet clear that elevated GPER expression is a cause of or consequence from lung cancer progression. Functional analysis of the effect of GPER expression will facilitate further delineation of the role of GPER in lung cancer.

\section{Methods}

Cell lines and mouse lung tissues

Normal human bronchial epithelial cell lines HBEC2-E HBEC2-KT, and HBEC3-KT were kindly provided by Dr. John D. Minna [49]. HPL1D, an SV40-immortalized human small airway epithelial cell line derived from a female non-smoker without lung cancer [50] was kindly provided to us by Dr. T. Takahashi (Center of Neurological Diseases and Cancer, Nagoya University Graduate School of Medicine, Nagoya, Japan) and Dr. Hildegard M. Schuller, Department of Pathobiology, College of Veterinary Medicine, University of Tennessee, Knoxville, TN) [51,52]. Human lung adenocarcinoma cell lines A549, NCI-H1435, NCI-H1395, NCI-H1944, NCI-H1792, NCIH1793, NCI-H2073, NCI-H23, and NCI-H1299 and human breast cancer cell lines MCF-7 and T47D were purchased from ATCC (Manassas, VA, USA) and used within 10 passages from the time of purchase from ATCC. The growth conditions for each of these lines were described previously $[21,22]$. Cell culture media supplies obtained either from Invitrogen (Carlsbad, CA, USA) or Mediatech, Inc. (Manassas, VA, USA). All the experimental protocols, usage of human cell lines and chemicals have been approved by the Institutional Biosafety Committee (IBC) at University of Louisville. The mouse lung tumor tissue sections were obtained from MCA-BHT induced lung cancer mouse model (Elangovan et al unpublished). All the animal experimental protocols have been approved by the Institutional Animal Care and Use Committee (IACUC) at University of Louisville.

\section{RNA isolation, CDNA synthesis, RT PCR}

Total RNA was isolated using Qiagen RNAasy mini kit (Qiagen, Valencia, CA, USA) according to manufactures' protocols and as described [21,22]. The isolated total RNA was treated with DNAse followed by synthesis of cDNA by reverse transcriptase (Applied Biosystems, Carlsbad, CA, USA). The similar reaction was also performed without reverse transcriptase as a control. The regular PCR reaction with Mango Taq Polymerase was performed on the above cDNA samples as templates to detect the presence of GPER using specific primers (FP $5^{\prime}$ AgTCGG ATGTGAGGTTCAG $3^{\prime}$ and RP $5^{\prime}$ TC TGTGT GAGGAGTGCAAG $3^{\prime}$ ) for GPER and Human ribosomal phosphor-protein (36B4) as reference marker [76]. The PCR was also performed on the cDNA reaction mix that did not contain reverse transcriptase as a negative control.

\section{Real time PCR}

For quantitative real-time PCR, $1 \mu \mathrm{g}$ of total RNA was reverse transcribed in $50 \mu \mathrm{l}$ reaction using TaqMan reverse transcription reagents (Applied Biosystems) using random hexamer primers. $2 \mu \mathrm{l}$ of cDNA and the $1 \mu \mathrm{M}$ real time PCR primers were used in a final $20 \mu \mathrm{l}$ qPCR reaction with 'power SYBR-green master mix' (Applied Biosystems). The sequences of the real time primers as follows: hGPER FP: $5^{\prime}$ AGTCGGATGTGAGGTTCAG 3'; hGPER RP: $5^{\prime}$ TCTGTGTGAGGAGTGCAAG $3^{\prime}$ [81]; h36B4 FP: 5' CTCAACATCTCCCCCTTCTC 3; h36B4 RP: 5' CAAATCCCATATCCTCGTCC 3'. Real time qPCR was performed in ABI-Prism 7900 sequence detect system (Applied Biosystems). Expression of the target genes was normalized to ribosomal phosphoprotein (36B4) and displayed as fold change relative to the wild type sample.

\section{Western blots}

The cell lysates were prepared using RIPA plus buffer. $10 \mu \mathrm{g}$ of total lysates were loaded on to SDS PAGE gels and detected using antibodies anti-GPER antibodies (Novus Biologicals, Littleton, CO, USA), Santa Cruz Biotechnology Inc (Santa Cruz, CA, USA). The membrane was stripped and used for beta-actin detection with antibeta-actin-HRP antibody (Santa Cruz Biotechnology Inc.). The GPER antibodies obtained from Novus Biologicals were raised against synthetic peptide contain a sequence corresponding to a region within amino acids 244 and 306 (NBP1 31239) and second one against the synthetic peptide [KLH conjugated] made to the C-terminal of human GPER (NLS 4272). Another antibody from Santa Cruz Biotechnology Inc. is raised against internal region of human GPER. $\beta$-Actin-HRP antibody obtained from Santa Cruz Biotechnology Inc.

\section{Immunohistochemistry}

The paraffin embedded lung tumor tissue sections were routinely deparaffinized and endogenous peroxidase was quenched with $3 \% \mathrm{H}_{2} \mathrm{O}_{2}$ in 1XPBS. The epitope retrieval was performed by heating for $30 \mathrm{~min}$ in sodium citrate buffer (pH6.0) in a water bath at $95-100^{\circ} \mathrm{C}$. The antiGPER antibody (Novus Biologicals) and isotype control used as primary antibodies. After $1 \mathrm{hr}$ incubation with the primary antibody at room temperature, the slides were washed twice with 1XPBS (5 min per wash), and then incubated with the secondary antibody solution for $30 \mathrm{~min}$ at room temperature. Visualization of GPER positive cells was done by using $\mathrm{ABC}$ staining system (Santa Cruz Biotechnology). Negative controls for all staining were done by omitting primary antibodies as well as use of isotype control antibodies. The sections were evaluated by Aperio Imagescope and quantified the number of positive cells at 200x magnification. 


\section{Tissue microarrays}

Human lung cancer (LC 242, LC1005) and breast cancer (BR 241) tissue microarrays used in this study were purchased from US Biomax Inc. (Rockville, MD, USA).

\section{Scoring of GPER expression}

The scoring of the GPER staining was performed by Swarupa Gadre, M.D., pathologist, U of L and reconfirmed by an independent pathologist, A. Bennett Jensen, M.D., Brown Cancer Center, U of L. The scoring pattern for GPER staining as follows: Score 0, negative staining for all cells; score $1+$, weakly positive for cytosolic staining in $<10 \%$ of cells; score $2+$, moderate to strong positive staining covering between 10 to $50 \%$ of cells and score $3+$, strongly positive staining including $>50 \%$ cells. For statistical purposes IHC scores were grouped into two groups, negative or weakly positive $(0$ and $1+)$ and moderately to strongly positive $(2+$ and $3+)$. All the scoring was done in a blinded manner to tumor type/stage data of tissue microarray. The pairwise comparisons were performed (cancer vs adjacent tissues as well as cancer vs normal lung tissues) using Mann-Whitney U test in Graphpad Prism software.

\section{Additional file}

Additional file 1: Figure S1. The semi-quantitative PCR of GPER (GPR30) in lung adenocarcinoma cells. RNA was isolated from each of the indicated cell lines and the cDNA was prepared as described in methods section. The semi-quantitative was performed using GPR30 primers and human ribosomal phosphoprotein (36B4) as reference as described Methods.

\section{Abbreviations}

GPR30/GPER: G-Protein coupled estrogen receptor 1; $E_{2}$ : 17- $\beta$ estradiol; ER: Estrogen receptor; ERE: Estrogen responsive element; EGFR: Epidermal growth factor receptor; MAPK: Mitogen activated protein kinase; NSCLC: Non-small cell lung carcinoma; TMA: Tissue micro array.

\section{Competing interests}

The authors declare no competing financial interests.

\section{Authors' contributions}

Dr. VRJ designed and performed the experiments as well as written the manuscript. Ms. R performed some of the GPCR and western blot experiments. Dr. B participated in design of research and writing of the manuscript. Dr. CMK provided the RNA and lung adenocarcinoma cell line samples, was involved in discussions for the design of experiments, performed calculations on the experiments performed by Ms. R, and contributed to the writing of the manuscript. All authors read and approved the final manuscript.

\section{Acknowledgements}

We thank Haritha Pallam for expert technical assistance in immunohistochemistry experiments and Drs. Swarupa Gadre and A.Bennett Jenson for scoring GPER expression levels. We thank Susan M. Dougherty for her cell work in select experiments. This work was supported by James Graham Brown Cancer Center at U of L and Kentucky Lung Cancer Program (KLCRP) grants to Drs. Jala and Klinge and by NIH R01 DK053220 to Dr. Klinge.

\section{Author details}

'James Graham Brown Cancer Center, Department of Microbiology and Immunology, 505 South Hancock Street, Room 323, CTR Building, Louisville, KY 40202, USA. ${ }^{2}$ Department of Biochemistry and Molecular Biology, and Center for Genetics and Molecular Medicine, University of Louisville School of Medicine, Louisville, KY 40202, USA.

Received: 26 October 2012 Accepted: 19 December 2012

Published: 28 December 2012

\section{References}

1. Siegel R, Ward E, Brawley O, Jemal A: Cancer statistics, 2011. CA Cancer J Clin 2011, 61:212-236.

2. Ramchandran K, Patel JD: Sex Differences in Susceptibility to Carcinogens. Semin Oncol 2009, 36:516-523.

3. Kiyohara C, Ohno Y: Sex differences in lung cancer susceptibility: a review. Gender Medicine 2010, 7:381-401.

4. Bouchardy C, Benhamou S, Schaffar R, Verkooijen HM, Fioretta G, Schubert H, Vinh-Hung V, Soria J-C, Vlastos G, Rapiti E: Lung cancer mortality risk among breast cancer patients treated with anti-estrogens. Cancer 2011, 117:1288-1295.

5. Dubey S, Siegfried JM, Traynor AM: Non-small-cell lung cancer and breast carcinoma: chemotherapy and beyond. Lancet Oncol 2006, 7:416-424.

6. Pietras RJ, Marquez DC, Chen HW, Tsai E, Weinberg O, Fishbein M: Estrogen and growth factor receptor interactions in human breast and non-small cell lung cancer cells. Steroids 2005, 70:372-381.

7. Drummond AE, Britt KL, Dyson M, Jones ME, Kerr JB, O'Donnell L, Simpson ER, Findlay JK: Ovarian steroid receptors and their role in ovarian function. Mol Cell Endocrinol 2002, 191:27-33.

8. O'Donnell L, Robertson KM, Jones ME, Simpson ER: Estrogen and spermatogenesis. Endocr Rev 2001, 22:289-318.

9. McEwen B: Estrogen actions throughout the brain. Recent Prog Horm Res 2002, 57:357-384

10. Yager JD, Davidson NE: Estrogen carcinogenesis in breast cancer. N Engl J Med 2006, 354:270-282.

11. Townson SM, O'Connell P: Identification of estrogen receptor alpha variants in breast tumors: implications for predicting response to hormonal therapies. J Surg Oncol 2006, 94:271-273.

12. Cavalieri E, Frenkel K, Liehr JG, Rogan E, Roy D: Estrogens as endogenous genotoxic agents-DNA adducts and mutations. J Natl Cancer Inst Monogr 2000, 2000:75-93.

13. Nilsson S, Makela S, Treuter E, Tujague M, Thomsen J, Andersson G, Enmark E, Pettersson K, Warner M, Gustafsson JA: Mechanisms of estrogen action. Physiol Rev 2001, 81:1535-1565.

14. Zhao C, Gao H, Liu Y, Papoutsi Z, Jaffrey S, Gustafsson J-Å, Dahlman-Wright K: Genome-Wide Mapping of Estrogen Receptor- $\beta$-Binding Regions Reveals Extensive Cross-Talk with Transcription Factor Activator Protein1. Cancer Res 2010, 70:5174-5183.

15. Lumachi F, Luisetto G, Basso SM, Basso U, Brunello A, Camozzi V: Endocrine therapy of breast cancer. Curr Med Chem 2011, 18:513-522.

16. Kuiper GG, Carlsson B, Grandien K, Enmark E, Haggblad J, Nilsson S, Gustafsson JA: Comparison of the ligand binding specificity and transcript tissue distribution of estrogen receptors alpha and beta. Endocrinology 1997, 138:863-870.

17. Mollerup S, Jorgensen K, Berge G, Haugen A: Expression of estrogen receptors alpha and beta in human lung tissue and cell lines. Lung Cancer 2002, 37:153-159.

18. Stabile LP, Davis AL, Gubish CT, Hopkins TM, Luketich JD, Christie N Finkelstein S, Siegfried JM: Human non-small cell lung tumors and cells derived from normal lung express both estrogen receptor alpha and beta and show biological responses to estrogen. Cancer Res 2002, 62:2141-2150

19. Stabile LP, Lyker JS, Gubish CT, Zhang W, Grandis JR, Siegfried JM: Combined targeting of the estrogen receptor and the epidermal growth factor receptor in non-small cell lung cancer shows enhanced antiproliferative effects. Cancer Res 2005, 65:1459-1470.

20. Dougherty SM, Mazhawidza W, Bohn AR, Robinson KA, Mattingly KA Blankenship KA, Huff MO, McGregor WG, Klinge CM: Gender difference in the activity but not expression of estrogen receptors alpha and beta in human lung adenocarcinoma cells. Endocr Relat Cancer 2006, 13:113-134. 
21. Ivanova MM, Mazhawidza W, Dougherty SM, Klinge CM: Sex Differences in Estrogen Receptor Subcellular Location and Activity in Lung Adenocarcinoma Cells. Am J Respir Cell Mol Biol 2010, 42:320-330.

22. Ivanova MM, Mazhawidza W, Dougherty SM, Minna JD, Klinge CM: Activity and intracellular location of estrogen receptors [alpha] and [beta] in human bronchial epithelial cells. Mol Cell Endocrinol 2009, 205:12-21.

23. Watson CS, Jeng Y-J, Kochukov MY: Nongenomic Signaling Pathways of Estrogen Toxicity. Toxicol Sci 2010, 115:1-11.

24. Jeng $Y-J$, Kochukov M, Watson C: Membrane estrogen receptor-alphamediated nongenomic actions of phytoestrogens in GH3/B6/F10 pituitary tumor cells. J Mol Signal 2009, 4:2.

25. Wyckoff MH, Chambliss KL, Mineo C, Yuhanna IS, Mendelsohn ME, Mumby SM, Shaul PW: Plasma membrane estrogen receptors are coupled to endothelial nitric-oxide synthase through Galpha(i). J Biol Chem 2001, 276:27071-27076.

26. Kelly MJ, Levin ER: Rapid actions of plasma membrane estrogen receptors. Trends Endocrinol Metab 2001, 12:152-156.

27. Levin ER: Minireview: Extranuclear Steroid Receptors: Roles in Modulation of Cell Functions. Mol Endocrinol 2011, 25:377-384.

28. Razandi M, Pedram A, Park ST, Levin ER: Proximal events in signaling by plasma membrane estrogen receptors. J Biol Chem 2003, 278:2701-2712.

29. Zhang G, Liu X, Farkas AM, Parwani AV, Lathrop KL, Lenzner D, Land SR, Srinivas H: Estrogen Receptor Beta Functions through Non-genomic Mechanisms in Lung Cancer Cells. Mol Endocrinol 2009, 23:137-145.

30. Majidi M, Al-Wadei HA, Takahashi T, Schuller HM: Nongenomic beta estrogen receptors enhance beta1 adrenergic signaling induced by the nicotinederived carcinogen 4-(methylnitrosamino)-1-(3-pyridyl)-1-butanone in human small airway epithelial cells. Cancer Res 2007, 67:6863-6871.

31. Levin ER: Cell localization, physiology, and nongenomic actions of estrogen receptors. J App/ Physiol 2001, 91:1860-1867.

32. Audy MC, Vacher $P$, Duly B: 17 beta-estradiol stimulates a rapid $\mathrm{Ca} 2+$ influx in LNCaP human prostate cancer cells. Eur J Endocrinol 1996, 135:367-373.

33. Morley P, Whitfield JF, Vanderhyden BC, Tsang BK, Schwartz JL: A new, nongenomic estrogen action: the rapid release of intracellular calcium. Endocrinology 1992, 131:1305-1312.

34. Aronica SM, Kraus WL, Katzenellenbogen BS: Estrogen action via the CAMP signaling pathway: stimulation of adenylate cyclase and CAMP-regulated gene transcription. Proc Natl Acad Sci U S A 1994, 91:8517-8521.

35. Le Mellay V, Grosse B, Lieberherr M: Phospholipase $C$ beta and membrane action of calcitriol and estradiol. J Biol Chem 1997, 272:11902-11907.

36. Song RX, Santen RJ: Membrane initiated estrogen signaling in breast cancer. Biol Reprod 2006, 75:9-16.

37. Manavathi B, Kumar R: Steering estrogen signals from the plasma membrane to the nucleus: two sides of the coin. J Cell Physiol 2006, 207:594-604.

38. Filardo EJ: Epidermal growth factor receptor (EGFR) transactivation by estrogen via the G-protein-coupled receptor, GPR30: a novel signaling pathway with potential significance for breast cancer. J Steroid Biochem Mol Biol 2002, 80:231-238.

39. Filardo EJ, Quinn JA, Bland Kl, Frackelton AR Jr: Estrogen-induced activation of Erk-1 and Erk-2 requires the G protein-coupled receptor homolog, GPR30, and occurs via trans-activation of the epidermal growth factor receptor through release of HB-EGF. Mol Endocrinol 2000, 14:1649-1660.

40. Filardo EJ, Graeber CT, Quinn JA, Resnick MB, Giri D, DeLellis RA, Steinhoff MM, Sabo E: Distribution of GPR30, a seven membrane-spanning estrogen receptor, in primary breast cancer and its association with clinicopathologic determinants of tumor progression. Clin Cancer Res 2006, 12:6359-6366.

41. Prossnitz ER, Arterburn JB, Smith HO, Oprea TI, Sklar LA, Hathaway HJ: Estrogen signaling through the transmembrane $\mathrm{G}$ protein-coupled receptor GPR30. Annu Rev Physiol 2008, 70:165-190.

42. Prossnitz ER, Maggiolini M: Mechanisms of estrogen signaling and gene expression via GPR30. Mol Cell Endocrinol 2009, 308:32-38.

43. Levin ER: G Protein-Coupled Receptor 30: Estrogen Receptor or Collaborator? Endocrinology 2009, 150:1563-1565.

44. Ariazi EA, Brailoiu E, Yerrum S, Shupp HA, Slifker MJ, Cunliffe HE, Black MA, Donato AL, Arterburn JB, Oprea TI, et al: The G Protein-Coupled Receptor GPR30 Inhibits Proliferation of Estrogen Receptor-Positive Breast Cancer Cells. Cancer Res 2010, 70:1184-1194.

45. Langer G, Bader B, Meoli L, Isensee J, Delbeck M, Noppinger PR, Otto C: A critical review of fundamental controversies in the field of GPR30 research. Steroids 2010, 75:603-610.
46. Barton M: Position paper: The membrane estrogen receptor GPER/GPR30: Clues and questions. Steroids 2012, 77:935-942.

47. Carmeci C, Thompson DA, Ring HZ, Francke U, Weigel RJ: Identification of a gene (GPR30) with homology to the G-protein-coupled receptor superfamily associated with estrogen receptor expression in breast cancer. Genomics 1997, 45:607-617.

48. Feng Y, Gregor P: Cloning of a Novel Member of the G Protein-Coupled Receptor Family Related to Peptide Receptors. Biochem Biophys Res Commun 1997, 231:651-654.

49. Ramirez RD, Sheridan S, Girard L, Sato M, Kim Y, Pollack J, Peyton M, Zou Y, Kurie JM, Dimaio JM, et al: Immortalization of human bronchial epithelial cells in the absence of viral oncoproteins. Cancer Res 2004, 64:9027-9034.

50. Masuda A, Kondo M, Saito T, Yatabe Y, Kobayashi T, Okamoto M, Suyama M, Takahashi T, Takahashi T: Establishment of Human Peripheral Lung Epithelial Cell Lines (HPL1) Retaining Differentiated Characteristics and Responsiveness to Epidermal Growth Factor, Hepatocyte Growth Factor, and Transforming Growth Factor $\beta 1$. Cancer Res 1997, 57:4898-4904.

51. Al-Wadei HAN, Al-Wadei MH, Masi T, Schuller HM: Chronic exposure to estrogen and the tobacco carcinogen NNK cooperatively modulates nicotinic receptors in small airway epithelial cells. Lung Cancer 2010, 69:33-39.

52. Schuller HM, AI-Wadei HAN, Majidi M: Gamma-aminobutyric acid, a potential tumor suppressor for small airway-derived lung adenocarcinoma. Carcinogenesis 2008, 29:1979-1985.

53. Maiti K, Paul JW, Read M, Chan EC, Riley SC, Nahar P, Smith R: G-1-Activated Membrane Estrogen Receptors Mediate Increased Contractility of the Human Myometrium. Endocrinology 2011, 152:2448-2455.

54. Milligan G, Canals M, Pediani JD, Ellis J, Lopez-Gimenez JF: The role of GPCR dimerisation/oligomerisation in receptor signalling. Ernst Schering Found Symp Proc 2006, 2006:145-161

55. Rios CD, Jordan BA, Gomes I, Devi LA: G-protein-coupled receptor dimerization: modulation of receptor function. Pharmacology \&amp; Therapeutics 2001, 92:71-87.

56. Sandén C, Broselid S, Cornmark L, Andersson K, Daszkiewicz-Nilsson J, Mårtensson UEA, Olde B, Leeb-Lundberg LMF: G Protein-Coupled Estrogen Receptor 1/G Protein-Coupled Receptor 30 Localizes in the Plasma Membrane and Traffics Intracellularly on Cytokeratin Intermediate Filaments. Mol Pharmacol 2011, 79:400-410.

57. Giess M, Lattrich C, Springwald A, Goerse R, Ortmann O, Treeck O: GPR30 gene polymorphisms are associated with progesterone receptor status and histopathological characteristics of breast cancer patients. The Journal of steroid biochemistry and molecular biology 2010, 118:7-12.

58. Prossnitz ER, Barton M: The G-protein-coupled estrogen receptor GPER in health and disease. Endocrinology: Nature reviews; 2011.

59. Tu G, Hu D, Yang G, Yu T: The correlation between GPR30 and clinicopathologic variables in breast carcinomas. Technol Cancer Res Treat 2009, 8:231-234.

60. Smith HO, Leslie KK, Singh M, Qualls CR, Revankar CM, Joste NE, Prossnitz ER: GPR30: a novel indicator of poor survival for endometrial carcinoma. Am J Obstet Gynecol 2007, 196(386):e381-e389. discussion 386 e389-311.

61. Vivacqua A, Bonofiglio D, Recchia AG, Musti AM, Picard D, Ando S, Maggiolini M: The G protein-coupled receptor GPR30 mediates the proliferative effects induced by 17 beta-estradiol and hydroxytamoxifen in endometrial cancer cells. Mol Endocrinol 2006, 20:631-646.

62. Smith HO, Arias-Pulido H, Kuo DY, Howard T, Qualls CR, Lee SJ, Verschraegen CF, Hathaway HJ, Joste NE, Prossnitz ER: GPR30 predicts poor survival for ovarian cancer. Gynecol Oncol 2009, 114:465-471.

63. Vivacqua A, Bonofiglio D, Albanito L, Madeo A, Rago V, Carpino A, Musti AM, Picard D, Ando S, Maggiolini M: 17beta-estradiol, genistein, and 4hydroxytamoxifen induce the proliferation of thyroid cancer cells through the g protein-coupled receptor GPR30. Mol Pharmacol 2006, 70:1414-1423.

64. Luo HJ, Luo P, Yang GL, Peng QL, Liu MR, Tu G: G-protein Coupled Estrogen Receptor 1 Expression in Primary Breast Cancers and Its Correlation with Clinicopathological Variables. J Breast Cancer 2011, 14:185-190.

65. Arias-Pulido H, Royce M, Gong Y, Joste N, Lomo L, Lee SJ, Chaher N, Verschraegen C, Lara J, Prossnitz ER, Cristofanilli M: GPR30 and estrogen receptor expression: new insights into hormone dependence of inflammatory breast cancer. Breast Cancer Res Treat 2010, 123:51-58.

66. Krakstad C, Trovik J, Wik E, Engelsen IB, Werner HM, Birkeland E, Raeder MB, Oyan AM, Stefansson IM, Kalland KH, et al: Loss of GPER identifies new 
targets for therapy among a subgroup of ERalpha-positive endometrial cancer patients with poor outcome. Br J Cancer 2012, 106:1682-1688.

67. Gao F, Ma X, Ostmann AB, Das SK: GPR30 Activation Opposes EstrogenDependent Uterine Growth via Inhibition of Stromal ERK1/2 and Estrogen Receptor Alpha (ERa) Phosphorylation Signals. Endocrinology 2011, 152:1434-1447.

68. Fasco MJ, Hurteau GJ, Spivack SD: Gender-dependent expression of alpha and beta estrogen receptors in human nontumor and tumor lung tissue. Mol Cell Endocrinol 2002, 188:125-140.

69. Stabile LP, Siegfried JM: Sex and gender differences in lung cancer. J Gend Specif Med 2003, 6:37-48.

70. Siegfried JM, Hershberger PA, Stabile LP: Estrogen receptor signaling in lung cancer. Semin Oncol 2009, 36:524-531.

71. Otto C, Rohde-Schulz B, Schwarz G, Fuchs I, Klewer M, Brittain D, Langer G, Bader B, Prelle K, Nubbemeyer R, Fritzemeier KH: G protein-coupled receptor 30 localizes to the endoplasmic reticulum and is not activated by estradiol. Endocrinology 2008, 149:4846-4856.

72. Kang L, Zhang X, Xie Y, Tu Y, Wang D, Liu Z, Wang ZY: Involvement of estrogen receptor variant ER-alpha36, not GPR30, in nongenomic estrogen signaling. Mol Endocrinol 2010, 24:709-721.

73. Otto C, Fuchs I, Kauselmann G, Kern H, Zevnik B, Andreasen P, Schwarz G, Altmann $\mathrm{H}$, Klewer M, Schoor M, et al: GPR30 does not mediate estrogenic responses in reproductive organs in mice. Biol Reprod 2009, 80:34-41.

74. Ahola TM, Alkio N, Manninen T, Ylikomi T: Progestin and G proteincoupled receptor 30 inhibit mitogen-activated protein kinase activity in MCF-7 breast cancer cells. Endocrinology 2002, 143:4620-4626.

75. Ahola TM, Manninen T, Alkio N, Ylikomi T: G protein-coupled receptor 30 is critical for a progestin-induced growth inhibition in MCF-7 breast cancer cells. Endocrinology 2002, 143:3376-3384.

76. Ahola TM, Purmonen S, Pennanen P, Zhuang YH, Tuohimaa P, Ylikomi T: Progestin upregulates G-protein-coupled receptor 30 in breast cance cells. Eur J Biochem 2002, 269:2485-2490.

77. Albanito L, Madeo A, Lappano R, Vivacqua A, Rago V, Carpino A, Oprea Tl, Prossnitz ER, Musti AM, Ando S, Maggiolini M: G Protein-Coupled Receptor 30 (GPR30) Mediates Gene Expression Changes and Growth Response to 17\{beta\}-Estradiol and Selective GPR30 Ligand G-1 in Ovarian Cancer Cells. Cancer Res 2007, 67:1859-1866.

78. Thomas P, Pang Y, Filardo EJ, Dong J: Identity of an Estrogen Membrane Receptor Coupled to a G Protein in Human Breast Cancer Cells. Endocrinology 2005, 146:624-632.

79. Giovannetti E, Erdem L, Olcay E, Leon LG, Peters GJ: Influence of polymorphisms on EGFR targeted therapy in non-small-cell lung cancer. Front Biosci 2011, 16:116-130

80. Keedy VL, Temin S, Somerfield MR, Beasley MB, Johnson DH, McShane LM, Milton DT, Strawn JR, Wakelee HA, Giaccone G: American Society of Clinical Oncology Provisional Clinical Opinion: Epidermal Growth Factor Receptor (EGFR) Mutation Testing for Patients With Advanced Non-Small-Cell Lung Cancer Considering First-Line EGFR Tyrosine Kinase Inhibitor Therapy. J Clin Oncol 2011,

81. Girgert R, Emons G, Grundker C: Inactivation of GPR30 reduces growth of triple-negative breast cancer cells: possible application in targeted therapy. Breast Cancer Res Treat 2012, 134:199-205.

doi:10.1186/1471-2407-12-624

Cite this article as: Jala et al.: Enhanced expression of G-protein coupled estrogen receptor (GPER/GPR30) in lung cancer. BMC Cancer 2012 12:624.

\section{Submit your next manuscript to BioMed Central and take full advantage of:}

- Convenient online submission

- Thorough peer review

- No space constraints or color figure charges

- Immediate publication on acceptance

- Inclusion in PubMed, CAS, Scopus and Google Scholar

- Research which is freely available for redistribution 